\title{
From Queen's Librarian to Voice of the Neapolitan Republic: Eleonora de Fonseca Pimentel
}

\author{
Irene Zanini-Cordi
}

\begin{abstract}
A poetess, translator and journalist, Eleonora de Fonseca Pimentel was born in $175^{2}$ in Rome into a liberal family. ${ }^{1}$ When her family moved to Naples, she thrived in the Arcadic circles of a city favourable to learned women. Pimentel started her career as a court poet, and then became the Queen's librarian. Following a tragic marriage and separation from her husband, she requested a state pension and translated from the Portuguese two books on economy and law, which supported specific political stances of the King. In 1798, she was accused of Jacobinism, imprisoned and deprived of her librarian post and pension. Her journalistic activity culminated in her becoming director and editor of the Monitore Napoletano (1799), the paper of the short-lived Republic, before being publicly hanged in August 1799. This chapter addresses the course of Pimentel's writings in relation to her economic situation. It shows that her literary production evolved according to the development of her political thought, which, in turn, mirrored her economic status.

Forsan et haec olim meminisse juvabit

Perhaps, one day, even this will be good to remember VIRgIL, Aeneid, I, 203
\end{abstract}

According to Vincenzo Cuoco, these are the last words that Pimentel pronounced on 20 August 1799, before stepping onto the scaffold in Napoli's Piazza Mercato. They are the words that Aeneas uses to console his surviving troops after they are shipwrecked on the shores of Carthage. It is only natural

1 For readability purposes I will refer to Eleonora de Fonseca Pimentel as Pimentel. 
to assume that Pimentel was directly referring to the events that led to the declaration of the Neapolitan Republic on 22 January 1799 and the fierce persecution of the patriots in June of the same year led by the inept Ferdinand IV, King of the Two Sicilies, and his vengeful spouse Maria Carolina.

In hindsight, we can appreciate the prophetic irony of Pimentel's wish as the royals did everything in their power to erase any memory of the Neapolitan Revolution, which started with the destruction of all personal documents and portraits pertaining to its most prominent proponents. This reactionary move was very successful in obliterating facts, names and images from the popular conscience, and achieved its goal also by controlling the mechanisms of private and collective memory. ${ }^{2}$ Not only was Pimentel denied the nobility's privilege of being decapitated instead of hanged, but her body was also left on the gallows for some time instead of being immediately taken down. Finally, and because of a sudden rainstorm, it was buried quickly in an unmarked grave in a nearby churchyard, now inexistent. ${ }^{3}$

Only after Italian unification was it safe to let memories of that period emerge. In 1899, on the centenary of the Neapolitan Republic's birth, a group of scholars led by the philosopher Benedetto Croce collaborated to assemble an Albo stori$c o$ : a volume intended to reconstruct this historical period so instrumental to the birth of the Italian Risorgimento. It was Croce who brought Pimentel back to history; he even wrote one of his first monographs on her. In his portrait of her, he sketches the figure of a new intellectual, a typical product of the Neapolitan Revolution, a person who contributed her literary skills and philosophical beliefs to a committed political activism that ultimately claimed her life. However, if Croce was instrumental in recovering the figure of Pimentel the patriot, with the weight of his authority he managed to consign to oblivion, once again, a relevant part of her identity by denying her literary production any originality. 4

2 A. Orefice, La penna e la spada, Napoli 2009, 38.

3 Orefice's suggestive thesis is that Pimentel's body was secretly exhumed in 1845 together with her uncle's and cousin's, and buried in the Fonseca's family chapel in the cemetery of Poggioreale. There, next to the cell of a certain Antonio Fonseca (1859-1897) there is that of his supposed wife Eleonora, of which no other record can be found. In the above courtyard, an angel belonging to the sculptural group La Religione (1845) by Tito Angelini, would be pointing underground exactly towards the Fonseca's chapel and Eleonora's burial site.

4 "Eleonora de Fonseca Pimentel cannot be placed among the original thinkers and researchers who deserve a place in the history of a particular science or discipline. But we find this noble character of a woman always in first line in the intellectual and political battles of her time: in her vigorous mind is reflected the best culture of the time, and in her gentle soul it acquired warmth of feeling and energy of will" ("Eleonora de Fonseca Pimentel non può annoverarsi tra i pensatori e ricercatori originali cui spetta un posto nella storia di speciale 
In fact, he dismissed her poetry as "courtesan content in Metastasio-like form". ${ }^{5}$

It is well known that Croce strongly disliked Metastasio's poetry and that he did not nurture any sympathy for the Arcadia, to which Pimentel belonged. One has to wonder why it is only recently, with Elena Urgnani's La vicenda letteraria e politica di Eleonora de Fonseca Pimentel (1998), that we finally have a complete reconstruction and fair evaluation of this outstanding woman's literary production. ${ }^{6}$ It is undeniable that the paucity of extant official documents has played a role in preventing an accurate reconstruction of her figure; however, it is worth noting that as a woman, she crossed many lines and shattered social boundaries. The courtly environment of eighteenth-century Naples (at least for a while) seemed to encourage the visibility of women on the cultural scene, but the nineteenth-century political and cultural reaction stifled it. It is only with the recent developments of Italian feminist thought, and the desire to retrace a female genealogy through the recovery of figures of the past, that Pimentel has been restored to history despite all the contradictions that make her a representative of the later currents of Italian Enlightenment and a forerunner of Pre-Romanticism.

Recently discovered papers related to Pimentel's separation trial, which include her own testimony, were housed in the civil court and escaped the cleansing fury of the Restoration. These papers have allowed us to recover the personal history of this woman. The documents present a multifaceted picture of life as an abused wife and unfulfilled mother, which enhances our understanding of Pimentel as a member of the Arcadia, admirer and follower of Metastasio, court poet, Queen's librarian, translator, political activist and, finally, as journalist and director of the 35 numbers of the Monitore Napoletano (1799), the main newspaper of the Neapolitan Republic.

Urgnani has rightly pointed to the many similar experiences shared by $\mathrm{Pi}-$ mentel and Ugo Foscolo, both of them representing transitional figures of the intellectual movement towards modernity; writers who strive to find a meaningful role in civil society. Absorbing and interiorising the peculiar idealism and drive to social justice that characterised the so called Triennio giacobino

scienza o disciplina. Ma noi troviamo questa nobile tempra di donna sempre in prima linea nelle battaglie intellettuali e politiche dei suoi tempi: nella mente vigorosa di lei si rifletteva la migliore cultura allora viva, e nel suo animo gentile acquistava calore di sentimento ed energia di volontà"). B. Croce, La Rivoluzione Napoletana del 1799, Bari 1926, 4.

5 "Contenuto cortigiano in forma metastasiana". B. Croce, "Eleonora de Fonseca Pimentel", in Rassegna degli interessi femminili, Roma 1887, 42.

6 Elena Urgnani, La vicenda letteraria e politica di Eleonora de Fonseca Pimentel, Napoli 1998. 
(1796-1799), they both directed their writers' skills to political activism, which ultimately claimed Pimentel's life and condemned Foscolo to exile. Their journalistic activity was similar (Foscolo directed the Monitore Italiano from 1788 until 1789 and one can safely assume that Pimentel was aware of it while directing her Monitore Napoletano). Both also felt the need, with their translation activity, to open up the stale horizon of the Italian cultural debate to the more dynamic, European one. ${ }^{7}$

There is, however, at least one more trait that these two writers share as transitional figures of intellectuals shifting from the ancient regime into modernity: the power of economic imperatives. In Italian literature, the role played by the economic factor in this transformation of the intellectual - from court poet to politically engaged patriot - has yet to be given due analysis. It is a particularly difficult topic to address when considering women writers. In the eighteenth-century Italian world of letters, being a writer, translator or journalist was hardly considered a profession for women, let alone a reputable one. Publicity in any form, even connected to the printed word, was dangerous for a woman's modesty, especially if she was unmarried. Notably, the few exceptions are concentrated in the more cosmopolitan and culturally dynamic Venetian Republic. There, Luisa Bergalli Gozzi helped support her family by writing and publishing poems, plays, translations and even, at one point, by trying her luck as a theatre impresario. (See the chapter by Von Kulessa in this volume.) In spite of, and actually because of, these enterprising activities, her brother-in-law, the writer Carlo Gozzi, defamed her and ruined her reputation for posterity. One generation later, the teenager Elisabetta Caminer Turra, a contemporary of Pimentel, received her training as a journalist and translator in the Venetian workshop of her father, Domenico Caminer, who founded and directed L'Europa Letteraria and the Giornale Enciclopedico. However, her book reviews and epistolary correspondence with Italian and European intellectuals attracted fiery attacks on her reputation. They subsided only when she married the physician Antonio Turra, who allowed her to pursue her literary interests. She became the director of the journal Europa Letteraria and, once she moved to the mainland with her husband, she opened a publishing house in Vicenza: the Stamperia Turra. Unfortunately, she died poor, devastated by breast cancer, ostracised by the provincial community, assailed by creditors, and begging friends to help her get subscribers for her journal.

7 E. Urgnani, "L'opera letteraria di Eleonora de Fonseca Pimentel", Rivista di letteratura italiana, XV (1997), 290. 
What are the economic dynamics at play for an eighteenth-century woman who considers her writing a profession, a cultural and social mission, not just a personal, albeit educational, pastime? What influence does the economic factor have on her career and life in general? Assuming the validity of the assertion "the personal is political", and since the political almost always entails economics, one can posit also the validity of the statement "the personal is politics and economics". The destiny of an eighteenth-century Italian woman was still mostly a matter of politics and economics. How did economic issues drive and shape Pimentel's life, and her intellectual and political trajectory? How did her literary talent serve her material needs?

In the previously mentioned study, Benedetto Croce wondered:

How is it, that this woman, who still in 1790 appears to be a supporter of the rights of the prince and an encomiast of King Ferdinand, and rewarded and awarded a pension at court for her work on the chinea, few years later transforms herself into a fiery Jacobin who conspires against the State and plays no small part in the revolution of $1799 ?^{8}$

According to Croce, the answer to this question is to be found in the intensifying of the Bourbons' anti-revolutionary fanaticism motivated by the consequences of the French Revolution. This reactionary attitude clashed with the progressive ideals of the Neapolitan noble intellectuals who had been influenced by Jacobin ideals. Faced with an authoritative state and excluded from the government, the nobles rebelled. This is certainly a compelling explanation. However, I would add that in Pimentel's case the personal and economic vicissitudes she underwent were instrumental in making her understand the Neapolitan people in a more pragmatic way. I will argue that her literary production evolved according to the development of her political thought, which, in turn, mirrored her daily life experiences. At first, her ideas and poetic efforts were closely connected to the court's intellectual environment. They reflected both her formative milieu and her economic dependency on the court, with the legitimacy she derived from it. Later, however, when her social idealism became active political commitment, she faced poverty, while the strength of her journalistic production stemmed from the freedom granted by the power of ideals.

8 "Come mai questa donna, che ancora, nel 1790, appare sostenitrice dei diritti del principe ed encomiatrice del re Ferdinando, e premiata e pensionata a corte per la sua opera sulla chinea, qualche anno dopo, si cangia in un'ardente giacobina, che ordisce congiure contro lo Stato ed ha parte non piccola nella rivoluzione del 1799?" (Croce, La Rivoluzione, 22.) [All Italian texts are translated into English by me, Izc.] 


\section{Literary Beginnings: The Salons, the Arcadia and the Court}

The family of Pimentel's mother, Doña Caterina López de León, was from Lisbon and its male members, mostly lawyers, had ties with the Holy See. They were also very loyal to the King of Portugal who had rewarded Doña Caterina's father by bestowing on the daughter an annual pension. This pension, passed onto her by her mother, would determine Pimentel's destiny. Her father, Don Clemente Henríquez de Fonseca Pimentel Chaves, was a registered member of the nobility in Portugal. Doña Caterina and Don Clemente married in Rome in 1750, and Eleonora was born in 1752. Don Clemente's brother had also married one of Doña Caterina's sisters. In 176o, apparently in relation to the expulsion of the Jesuits from Portugal, the abbot Don Antonio López, one of Doña Caterina's brothers, moved the two López families to Naples. ${ }^{9}$

In Naples, thanks to Don Antonio's cultural network and his friendship with Josè de Sà Pereira, consul of Portugal, the young Pimentel had ready access to the best teachers in town and, later on, to the most popular literary salons that were also renowned abroad. ${ }^{10}$ In these gatherings, la portoghesina ("the little Portuguese") - fluent in Portuguese, Italian, French, English, Latin and Greek was famous for reciting elegant poems of her own composition. At the age of sixteen, she was admitted to the Neapolitan Accademia dei Filateti ("friends of truth") with the cumbersome name of Epolnifenora Olcesamante, an anagram of her forename and surname. Politically, the accademici supported the idea of social and human progress promoted by an enlightened monarchy. Thinkers, such as Pietro Giannone and Antonio Genovesi, left a strong imprint on Neapolitan intellectuals' thought, a drive to move away from Rome's political influence and to guide the sovereign in a politics of innovative social reforms. ${ }^{11}$

On 12 May 1768, on the occasion of the marriage of Ferdinand IV to Maria Carolina of Austria, Pimentel presented Il Tempio della Gloria (The Temple of Glory) at court. In this long and ambitious epithalamion, the encomiastic intention was accompanied, if not obscured, by a show of poetic skills and erudition. Sergio Minichini has noted that the collective expression of joy on the part of relatives, friends and courtiers, which is usually at the heart of such

$9 \quad$ F. Schiattarella, La Marchesa giacobina, Napoli 1973, 11.

10 Of particular importance was the literary salon of D. Francesco Vargas Maciucca, which was furnished with a beautiful library. Among the intellectuals who frequented it there were Filangieri and the brothers Domenico and Giuseppe Cirillo (future martyrs of the Neapolitan Republic). Pimentel was also introduced to the salon of Eleonora Fusco where, according to Croce, many intellectuals belonging to the Neapolitan nobility gathered.

11 Schiattarella, La Marchesa, 18-19. 
a composition, here only takes up the first four stanzas out of a total of 79 octaves. This would confirm, in his opinion, that the object of the composition was to obtain the personal benevolence of the royals and, more generally, it was an attempt to inspire enlightened reforms and to celebrate social progress. ${ }^{12}$ The poetess displays her erudition by reconstructing in detail the Bourbons' and Hapsburgs' genealogy and, where history fails, she employs myth to cast a heroic and divine aura on the royals.

This first work, however, also seems to aim at asserting the role of the female poet. It presents the realm of Venus as a locus amoenus where nature is moralised and the protagonist has to choose between "lovely girl" ("amabile Donzella") and "serious woman" ("Donna grave"), reflecting the dichotomy between pleasure and commitment to reality. At the heart of the poem, decorated with the simplicity of light and surrounded by the dynasties of the Hapsburg and the Bourbon, the Temple of Glory shines as the site of examples of virtue. It stands in contrast to the splendour of precious gems and metals of Venus' abode where the goddess is lost in an amorous embrace with Mars. If it is true that this juxtaposition between Athena and Venus, intellect and love/ heroism and pleasure, is part of Metastasio's vocabulary, it is also possible to read it as the desire of the woman poet to be considered on par with her male colleagues, to be taken seriously in her role of intellectual and to be viewed as a "Donna grave", not simply an "amabile donzella". 13

Despite its inevitable stylistic and compositional awkwardness (the poetess was only 16 years old!), this encomiastic epic poem reached its goal of granting its author greater visibility. It introduced Pimentel to the Queen and, quite probably, obtained her an invitation to join the Arcadia. In fact, she was inducted into the Arcadia that same year as Altidora Esperetusa, a name she used to sign her future compositions, but which does not appear on the frontispiece of Il Tempio della Gloria. ${ }^{14}$ This work was probably instrumental in initiating her correspondence with Metastasio (1770-1776), which thrived through the mediation of Giuseppe de Souza, the secretary to de Sà Pereira in Naples, who was later transferred to the Portuguese embassy in Vienna. The poetess' correspondence with the old imperial court poet was educational but, as we shall see, caused her some trouble.

\footnotetext{
12 S. Minichini, "Il Tempio della Gloria (1768)", in Eleonora Fonseca Pimentel. Una donna tra le muse ed. R. Giglio, Napoli 1999, 27.

13 Ibid., 29.

14 The Neapolitan colony of the Arcadia had become, under the leadership of the abbot Antonio Jerocades, a masonic lodge.
} 
The sonnet was one of the first poetic genres with which Pimentel experimented. Its malleable form allowed her the use of different registers, from the encomiastic and mythological to the more personal and realistic tone. She often experimented with language, even using, on a couple of occasions, the Neapolitan dialect. The first extant sonnet appeared in a 1770 collection printed in Naples for the occasion of the Carafa wedding. As Urgnani points out, it is noteworthy that this sonnet "The Goddess who Reigns in Pafo and Amantuta" (La Dea, ch'in Pafo, e in Amantuta Impera [= Venus, IZC]), appeared together with the literary homages of prominent Neapolitan intellectuals among which there is a composition by Mariangela Ardinghelli, a well-known woman of sciences and a translator. This could signal that Pimentel's society recognised the public intellectual role of women of letters and women of science. ${ }^{15}$ Clear proof that Pimentel had achieved fame outside Naples and, indeed, was considered among the most prominent Italian women writers, was the inclusion of her sonnet "Pretty Nightingale, Who with Sweet Notes" (Vago Usignol, che ne' Soave Accenti) in the 1773 volume, Rime di donne illustri a S. E. Caterina Dolfina cavaliera e procuratessa Tron (Poems of Illustrious Women to HE Caterina Dolfina Tron), edited by Luisa Bergalli Gozzi to celebrate her patroness' new role as first lady of the Serenissima. ${ }^{16}$ This work is relevant in Italian literature since through extensive archival research, and relying on the help of a network of scholars from all over Italy, Bergalli Gozzi managed to assemble an exhaustive volume of poetry representative of all the known Italian women poets from the Renaissance to the present. For the first time in Italian literature, a woman editor reconstructed an Italian literary female genealogy. Pimentel's presence inserts her firmly in a female poetical tradition. Her sonnet establishes a further relationship of 'sisterhood' with the dedicatee, Caterina Dolfin, a poetess and fellow Arcadian, by addressing the experience of pain at the loss of a parent that both women shared. ${ }^{17}$ Signing the sonnet with her Arcadian name, Altidora Esperetusa, Pimentel addresses Caterina Dolfin Tron in her role of poetess ("Vago usignol") mourning her father, and draws a parallel between their experiences. She closes the composition in quite an

\footnotetext{
15 Urgnani, La vicenda, 83.

16 L. Bergalli Gozzi, Rime di donne illustri a S.E. Caterina Dolfina cavaliera e procuratessa Tron, nel gloriosissimo ingresso alla dignità di procuratore per merito di S. Marco di S.E. il Cavaliere Andrea Tron, Venezia 1773, 34.

17 A very well educated and cultured woman, Caterina Dolfin was admitted into the Arcadia in 1757 with the name of Dorina Nonacrina. Her poetry dealt mostly with personal experience and grief for the death of her beloved father. After she managed to get her first marriage annulled, she married Andrea Tron thus becoming the most powerful woman in Venice and a patron of writers and artists.
} 
unexpected way by admitting her inability to focus on celebrating Caterina Dolfin Tron in her poem as she is overwhelmed by grief for the death of her own mother. ${ }^{18}$

Another sonnet from 1773 is addressed to a woman, Queen Maria Carolina, but it displays excessive subservience, especially for modern sensibility, by embracing the current patriarchal ideology. "It Will Come, Royal Woman, It Is Prescribed in the Sky" ("Verrà, Donna Real, è in Ciel prescritto"), is an attempt to comfort the Queen who, by birthing a second daughter instead of the desired male heir, had 'failed' in her official role and missed another chance to preside over the meetings of the State Council. This poem, which should be celebrating life, is instead postponing the celebration for the day of the "great delivery" ("gran parto"), because the two "Dawns" ("Aurore" [= daughters, IZC]) cannot but be its messengers, like dawn precedes the day.

Indeed, only two years later, in 1775 , Pimentel had the opportunity to celebrate the "gran parto". She saluted the birth of Charles, the heir to the throne, with the cantata "The Birth of Orpheus" (La Nascita di Orfeo), a work that assured her the prestigious position of Queen's librarian. Although Eleonora at this point in her life did not need a job, her encomiastic efforts finally paid off. She had acquired an official position at court that sanctioned her image in society as a woman of letters. Moreover, from a more political perspective, there was no better way of influencing the Queen's politics towards the prized social reformism desired by her circle of enlightened friends than by being in charge of the Queen's books.

This projection of idealistic hopes for the betterment of society through the power of the ruling class is evident in "La nascita d'Orfeo". A cantata is a musical form derived from the madrigal. Highly popular at court and in salon gatherings, it blended the vocal and instrumental, the recitative and the melodic. In general, Pimentel's cantatas, because of their formal complexity and high number of characters, strongly resemble miniature melodrammi: Metastasio mastered both forms. ${ }^{19}$ The son of Ferdinand IV and Maria Carolina is here hailed as Orpheus, the son of the god Apollo and the muse Calliope, destined to bring peace and to have a positive influence on society. This enlightened role for the prince is clearly explained in the Argomento where the poetess portrays

18 A sonnet dealing in a more conventional way with the theme of death was an epicedium published in a 1771 volume commemorating the death of Giovanni Capece, Bishop of Oria. "Allor, che sciolto da' mortali affanni" is certainly a more traditional poetic tribute although the poetess experiments by borrowing imagery and language from Dante. 
Orpheus as "founder of societies and maker of laws" ("fondatore di società e facitore di leggi") and, following his example,

The prince Charles of Bourbon, [...], perfecting the work of Orpheus, and finishing what his elders have wisely begun, will correct the abuses of society and will lift it to the highest, imperturbable, state of happiness and perfection. ${ }^{20}$

The dialogue between Pallas and Venus, who gifts the prince with wisdom and grace respectively, lays out the importance of the social contract by voicing two major drives within civil society: the necessity to see "the advantage of common life" ("il vantaggio della vita commune [sic]", Pallas, vv. 140-141) and the awareness that the functioning of society is not only based on need, but is inspired by reciprocal love (Venus). In Pimentel's open and unabashed praise of the royals, one can recognise - as Croce did - the general attitude of the intellectuals of the time who, like Voltaire with Catherine of Russia, simply perceived it as a way to promote the well-being of the peoples and to encourage a civilising effort - an attitude, which - at that moment - the King and Queen of Naples seemed to embrace. ${ }^{21}$

\section{An Unhappy Marriage and Economic Troubles}

Pimentel's life took a harsh turn in 1771. Her mother, terminally ill, decided to leave to her nineteen-year old "most dear, most loved and most esteemed daughter D. Eleonora" ("carissima, dilettissima e stimatissima figlia D. Eleonora") all her possessions. However, the inheritance was intended as a dowry, and would return to the family if she did not marry, died without children, or became a nun. Included in the inheritance was the already mentioned annual pension granted by the King. Finding a husband for Pimentel was the next step, and her maternal grandmother thought well of keeping the money in the family by arranging an engagement with her cousin Michele López, a lawyer. She went so far as to leave them all of her own possessions. The two cousins

20 "Il principe Carlo Borbone, [...], perfezionando l'opera di Orfeo, e traendo a fine ciò che hanno i suoi maggiori saviamente incominciato, correggerà gli abusi della società e la innalzerà all'ultimo imperturbabile stato di felicità e di perfezione". (E. de Fonseca Pimentel, La nascita di Orfeo, Napoli 1775.)

21 M. Porcelli, "La poesia di Eleonora de Fonseca Pimentel", in Eleonora de Fonseca Pimentel tra mito e storia ed. F. d'Episcopo, Napoli 2008, 38 . 
had grown up together and, apparently, had similar ambitious and independent personalities. However, when Michele López was sent to Malta in 1776 to obtain the "Royal Military Order of Malta" ("Sovrano Militare Ordine di Malta") to add to his family's prestige, he stopped correspondence with his fiancée. After writing many letters that went unanswered, the spurned Pimentel wrote one, which included a biting sonnet to Michele in which she bids him to choose between Malta and herself.

The engagement failed, but Pimentel's father found - what he thought was a good substitute in don Pasquale Tria de Solis, a subaltern in the royal army and twenty years her senior. The premises of an unhappy marriage could be predicted in the profound cultural differences between these two families: the Tria de Solis family was wealthy but prone to debt, religiously conservative and part of the military circles, while the De Fonseca family supported the Kingdom of Naples's independence from the Pope and mingled with the Enlightened and reformist intellectuals.

In the testimony for the separation trial, it is Pimentel's own voice that reconstructs for us her life as a married woman. It clearly spells out the psychological and physical abuse to which she was subjected, and the economic pressure she experienced. Once she moved into her husband's home, she had to deal with three unmarried, bigoted and cruel sisters-in-law. They disapproved of her literary activity and condemned her correspondence with other intellectuals as immoral conduct. Her husband refused to give her the stipulated monthly sum for her own personal expenses from the beginning, to the point that she had to buy a volume of Petrarch's poems and another of Guidi's with money from a small lottery win. With another lottery win, she subscribed to the volumes of the Encyclopédie. Her husband also harassed her for money to pay his own debts. To settle his debts she had to sell her jewelry and borrow money against her dowry. Her request for necessary items, such as a new dress for public functions, was met with firm refusal, to the point that she had to complain to her father and borrow from her brother. Most disconcerting is the narrative of how - because of her husband's violence - she lost her baby, and almost her own life, five months into her pregnancy:

One evening, not finding a volume on music of the translation of English Universal history, which I had borrowed, I addressed him saying that if the book were not to be found he should have had the diligence to look for it in some bookstand, to which one of his sisters answered angrily and he went on getting out of the bed where he was and, having taken me by my waist, threatened to throw me out of a nearby balcony; this sudden violent outburst produced in me such surprise, indignation and fear that 
I fainted, but not wishing to make it public nor to make a fuss at that moment I did not call a doctor; consequently I aborted a dead fetus and was in extreme danger of losing my life, saved almost miraculously by the skills of M. Pean's son. ${ }^{22}$

In her narrative, Pimentel ties this incident directly into the economic question. Not only was the husband incensed at the idea of having to buy a book for his wife, but he also refused, for a long time, to pay the Queen's surgeon who had taken care of her. This miscarriage inspired her to compose an elegiac ode, a striking work and definitely her most original poetical composition, in which scientific knowledge of the time and a pre-Romantic sensibility are the vehicles of her dramatic autobiographical experience. ${ }^{23}$ After this tragic event, Pimentel's books - her metonymic extension - became the primary target of the husbands' fury. He denied her access to them as well as to her circle of cultured friends. He even destroyed them since they undermined his total control of her:

[...] When I went back into my room I found the few books that were there all strewn on the floor, and the following day he came to the crazy decision to want to burn two little books of English letters containing the history of that island, and other books of nice French letters printed in Holland (both unknown languages to him), having argued from the language and from the publication place that they had to be heretical, maintaining that in his role of husband he could and wanted to control my actions and my conscience. ${ }^{24}$

22 “[...] non trovando una sera un tomo legato alla musica della traduzione della storia Universale inglese, statomi imprestato, mi rivolsi a lui dicendogli, che se il libro non si trovava, bisognava che egli usasse la diligenza di cercarlo in qualche bancarozza, al quale mio detto, rispondendo indisponente una delle sorelle, continuò egli alzandosi da sopra il letto dov'era, e presami all'improvviso per la vita, minacciò di gettarmi da un balcone vicino, il quale inaspettato eccesso produsse in me tanta sorpresa, indignazione e spavento che io ebbi a svenire, pur non volendo pubblicarlo né produrre rumore in quell'ora trascurai di chiamare professore alcuno; onde ne venne poi che io sconciassi d'estinto feto, e ne fossi in estremo pericolo della vita, quasi miracolosamente salvata dalla perizia di M. Pean il figlio". (Archivio di Stato di Napoli, fondo Gran Corte della Vicaria, ordinamento Zeni, fascio 133, fascicolo 43, 77-89. In Orefice, La penna, 61.)

23 "Ode elegiaca di Altidora Esperetusa per un aborto, nel quale fu maestrevolmente assistita da M.R Pean il figlio", in Sonetti di Altidora Esperetusa in morte del suo unico figlio, 1779, reprint by B. Croce, Napoli 1900.

24 " $[. .$.$] nel rientrare in camera ritrovai i pochi libri che vi erano tutti sparsi per terra, ed$ il giorno seguente giunse al pazzo furore di voler bruciare due libretti di epistole inglesi contenenti la storia di quell'isola, ed altri di belle lettere francesi stampate in Olanda 
The abuse escalates to the point that:

[...] In a situation where I was abandoned by almost everybody, the sisters had ease in oppressing me with actions and lies, and I was meanwhile prevented from freely commiserating with anybody, each step of mine was spied and each one of my writings or letters was read and intercepted..$^{25}$

Finding herself pregnant again, Pimentel asks Gen. Acton, the minister of war, to intervene by reprimanding her husband. Thanks to the help of de Souza, the secretary to the Portuguese ambassador, the sisters-in-law were sent to a monastery after a second miscarriage. Her "failure" to produce a male heir in turn brought her dowry into the Tria de Solis household worsening the family dynamics. Pimentel's husband brought his lover, a low-life "hatmaker" ("cuffiara"), and her young daughter, into the house. To remedy the enormous debts that her husband had contracted, especially with his own brother, Pimentel tried to legally prevent the seizure of all his belongings but was nonetheless forced to downsize the household and to move to a cheaper abode outside town, in a poor area. There, isolated from her relatives and friends, she was forced by her husband to depend on the services of his lover, and even to share her bed with this woman. Once informed about the shady past of her husband's lover, Pimentel managed to oust the woman and her daughter from the house. However, her husband openly continued his liaison and stopped providing for her:

[...] He did not talk to me anymore, he did not provide for daily food. I had to borrow on my word some money from friends, whom I have not paid back yet, and he even kept me for some days without anything. ${ }^{26}$

Finally, through her powerful friends, Pimentel obtained the King's intervention. His letter banned the husband's lover from the Neapolitan State and

(lingue ambe a lui ignote), sia avuto argomento della lingua, e dal luogo che dovessero essere ereticali, affermando che egli come marito poteva e voleva comandare le mie azioni e la mia coscienza". (E. de Fonseca Pimentel, "Separation trial testimony", in Orefice, $L a$ penna, 62.)

25 “[... ] rimessa io quasi abbandonata da tutti s'aprì insieme vasto campo alle sorelle d'opprimermi e coi fatti e con le calunnie, ed intanto veniva a me impedito il libero sfogo con chiunque, spiato ogni mio passo, e letto e intercettato qualunque mio scritto o biglietto". (Ibid.)

26 "[... piú meco non parlava, non provvedeva al giornaliero vitto. Perciocché dovetti io sulla propria parola incomodare di qualche somma gli amici, che non ho ancora soddisfatti, ed alcuni giorni, perfino senza cosa alcuna, mi mantenne". (Ibid., 68.) 
ordered Tria de Solis to cease abusing his wife. In 1784, her father, worried by the man's psychological and physical violence, instead intervened himself and brought his daughter back home. ${ }^{27}$ The separation trial was long and painful as Tria de Solis had kept his word when he declared that,

[...] He would have found all the means and ways to have his whore declared honest and innocent and, on the contrary, his wife a whore, accusing her of long-standing loves and connections that she had with men of letters. ${ }^{28}$

Indeed, a large number of letters from her intellectual friends, such as Metastasio and Alberto Fortis, had been intercepted by the sisters-in-law and turned up as proof of her wifely misconduct during the trial. (It did not help, for example, that in one of these letters Fortis thanked her for mending his linens.) With her father's sudden death in 1785 , Pimentel was deprived of the main emotional and psychological support in her battle against her husband. However, quite inexplicably, Tria de Solis decided to let the lawsuit drop and allowed Pimentel to move in with her maternal uncles.

During her marriage, Pimentel continued composing encomiastic poems, most of them extolling the reforming actions of the royals and celebrating their accomplishments. In the sonnet dedicated to Queen Maria Carolina for the inauguration of the Accademia (of Sciences and Letters, 5 May 1780), the poetess personifies wisdom, Sophia, and makes her travel the Orient finally to find her permanent residence in Naples, at the Accademia. According to an eyewitness, Pimentel was one of seven poets who recited their sonnets in the presence of both royals and she outperformed by far the other six, all priests. ${ }^{29}$ In February 1782, the heir to the Russian throne, Pavel Petrovich, and his wife Maria Fyodorovna, were travelling across Europe under cover as "The Count and Countess of

27 Her personal possessions, when she returned home, amounted to "Two trunks filled with undergarments and dresses for her own use, a poplar cabinet, a bookshelf with books that have been recognised as her own, two silver covers, a copper basin, two blankets - one of ermine, the other of crimson damask - a mattress and six pillows" ("due bauli pieni di biancheria e vesti per suo uso, uno stipone di pioppo, una scanzia con libri che si è detto esser propri di D. Eleonora, due posate di argento, un lavamano di rame, due coverte - una di armesino, l'altra di damasco cremisi - un materasso e sei cuscini"). In Archivio di Stato di Napoli, Processo di separazione, verbale di consegna, allegato. Cited in Schiattarella, La Marchesa, 61 .

28 " [...] avrebbe procurato tutti i mezzi e le vie per fare dichiarare onesta e innocente la sua puttana, e, all'incontro, puttana la moglie, con l'insinuazione di antichi amori e aderenze che essa teneva con uomini di lettere". (Ibid., 62.)

B. Croce, Curiosità storiche, Napoli 1921, 191. 
the North" and arrived in Naples. In all the courts they visited, their arrival was celebrated by festivities and marked by literary homages. For the event, Pimentel prepared a cantata, La Gioia d'Italia (The Joy of Italy), where she celebrated the grand-duke Paolo as son of Catherine the Empress of Russia, "new Pallas" ("Pallade novella"), venerated by intellectuals as an enlightened woman and, as indicated by the poetess, a potential model for Maria Carolina. ${ }^{30}$ Pimentel took advantage of this event to align herself with the likes of Voltaire in extolling the empress. The sonnet "The Genius of Empires" (Il Genio degl'Imperi) was published as an appendix to this cantata and was directly dedicated to the Russian empress. She is defined as "august and strong" ("augusta e forte") and endowed with "bellicose brilliance" ("bellicoso ingegno"), qualities that attract the "Genio degl'Imperi" to shower success on her since she governs "a more stable government" ("più stabil regno") which underscores her political talent.

\section{Economic Dependency on the Court}

If the end of the separation process brought Pimentel a much-needed peace, the death of her father left her in a precarious economic condition. She was forced to beg the King for help, maintaining that the monthly alimony check her husband had been ordered to pay her was insufficient, but that it was also highly unrealistic that she would receive it as he had too many creditors to satisfy. In August 1785, she was granted a small pension of 12 monthly ducats in light of her situation and poetic talent and, later on, she could count on a total of 28 monthly ducats that allowed her to maintain a dignified lifestyle. ${ }^{31}$ According to scholars, the cantata Il Vero Omaggio (The Real Homage), which

\footnotetext{
30 La gioia d'Italia. Cantata per l'arrivo in Napoli delle LL. AA. RR. Il Gran Duca e la Gran Duchessa delle Russie, Napoli 1782.

31 "Informato il Re dello stato infelice in cui si trova D.a Eleonora de Fonseca Pimentel, moglie del cap.no graduato di Sannio D. Pasquale Tria de Solis, da cui vive divisa, e volendo provvedere al sostentamento di tal Donna, la quale è ben degna della Sovrana Clemenza: non solamente in grazia dell'accennata infelicità, ma ancora de' suoi non ordinari talenti, che sono superiori alla sfera del suo sesso, comanda che alla detta D.a Eleonora si somministrino ducati dodici mensuali [...]". (The King having been informed of the unhappy situation encountered by D.a Eleonora de Fonseca Pimentel, wife of the decorated captain of Sannio D. Pasquale Tria de Solis, from whom she lives separated, and wishing to help support such Woman who is well deserving of his Highness' Clemency: not only because of her abovementioned unhappiness, but also because of her unordinary talents, which are superior to the sphere of her sex, he orders that she be given twelve ducats monthly). In Archivio di Stato di Napoli, Ministero Finanze, fasc. 972. Quoted in Schiattarella, La Marchesa, 94.
} 
is not dated but celebrates the return of the royals to Naples after a four-month stay in Sicily in 1785 (April 30-September 7), should be read as a token of gratitude on Pimentel's part for the pension she had just been granted. ${ }^{32}$ This cantata stages the presence of a number of local mythological figures and marine deities waiting for the arrival of the royals on the Bay of Naples while Sebeto (a river near Naples) and Partenope (ancient name for Naples) extoll the royals and compare them to the parents of the nation. On the frontispiece of the work, right below the author's name, appears an epigraph from Oratius's Carmina referring to the return of August to Rome: "as soon as your face appears in splendour to the people, the day passes more pleasing". ${ }^{33}$

The influence of the sovereign on his people, and his constructive interaction with them for the progress of humankind is a theme that will be developed even further in Pimentel's works. For example, her two sonnets celebrating the official inauguration of San Leucio in 1789 focus on the important role of the King in promoting civilisation. ${ }^{34}$ Ferdinand IV had set up a phalansterylike silk and brocade manufactory on the hill of San Leucio where 214 workers, of both sexes, toiled and lived together "In perfect equality of dressing, and absolute prohibition of luxury and communion of property". ${ }^{35}$ While in both sonnets Ferdinand IV is praised for the new laws he imposes on this community, one explicitly portrays him not only as the creator of an ideal society, but also as the reformer of society as a whole.

The newly found freedom from conjugal vexation and economic worries allowed Pimentel to focus completely on what she loved most, her studies, and to have a social life. During the second half of the eighteenth century, Naples was an important destination for Grand Tourists, artists and intellectuals. The Queen's librarian met, among other visitors, the archeologist Munter, the

32 Il vero omaggio. Cantata per celebrare il fausto ritorno delle loro maestà, Napoli 1785 . In Urgnani, La vicenda letteraria, 182.

33 “...vultus ubi tuus affulsit populo, gratior it dies", Orat., Carm., IV, 5, vv. 6-7.

34 In Componimenti poetici per le Leggi date alla nuova Popolazione di Santo Leucio da Ferdinando IV re delle Sicilie, Napoli 1789. This officially sponsored collection of tributes by the most illustrious intellectuals of the time is 240 pages long. It should be noted that Urgnani cites as her source for the two sonnets the abovementioned collection, preserved in the Biblioteca Nazionale di Napoli (140-D-28/2). However, D. De Liso in the chapter "Sonetti (1770-1798)" in Una donna tra le muse, ed. Giglio, claims that this collection only contains one sonnet, while Urgnani had probably consulted a different source, a miscellaneous collection preserved in the Società Napoletana di Storia Patria.

35 "In perfetta uguaglianza nel vestire, e assoluto divieto del lusso e comunione dei beni". Apparently, the King himself came up with the ceremonial for the colony, but there is scholarly agreement in attributing the idea to some members of the Gran Consiglio di Stato, an advisory council of reformist and masonic leaning. Ibid., 116. 
scientist Spallanzani, and the Veronese poetess Silvia Curtoni Verza. She had crossed paths with the famous naturalist Alberto Fortis in 1784 and had kept a friendly correspondence with him that caused her much trouble during the separation trial. This friendship, however, also brought her honour by association and placed her within the European Republic of Letters. ${ }^{36}$ As her communication to the Academy of Lisbon of Fortis' discovery of elephant bones testifies, she was active in a network of intellectuals exchanging ideas, facilitating the dissemination of information and of the latest scientific findings. Apparently, it was Alberto Fortis and Melchiorre Delfico, both friends of Filangieri, who supported her interests in economics and law, and encouraged her studies in those subjects.

In 1788 , for the first time, the "chinea issue" offered Pimentel the opportunity to intervene in a political debate. The homage of the chinea (which means "kneeling") was a yearly tribute, dating back to Charles of Anjou, that the King of Naples owed to the Pope as the Kingdom of Naples was considered a feud of the Papal State. The King's ambassador would lead a richly adorned white horse carrying a coffer with 7,00o ducats to kneel in front of the Pope during the celebration of Saint Peter. When at the beginning of the eighteenth century, the Emperor of Austria and King of Naples, Charles vI, refused to pay this tribute, Neapolitan jurists supported his position by claiming the independence of the Kingdom from the Holy See. ${ }^{37}$ However, the Bourbons thought best to keep a good relationship with the Pope and reinstated the chinea. Later on, Queen Maria Carolina, supported by the Prime Minister and by a sizeable portion of the Neapolitan intellectuals, did not see any need for this yearly humiliation. In 1789, Ferdinand IV refused to send the chinea, thus enraging the Pope. This controversy energised those opposing any claim of sovereignty by the Pope on the Neapolitan State (the De Fonseca Pimentels were among those) and motivated a flurry of literary and juridical writings.

Initially, Pimentel chimed in with poetry, a sonnet dedicated to Ferdinand IV. A choral "we" is used to voice the people's recognition first and foremost

36 Giuseppe Gorani, who was in Naples in 1786-1788, mentioned Pimentel in his Memoires secretes et critiques des cours, Paris $1793,76-77$ as "a lady who gathers in her home in Naples a society of literary people, great friend of all the illustrious people of this capital, and mostly of abbot Fortis" ("une dame qui rassemble chez elle à Naples une societé de gens de lettres, grande amie de tous les illustres de cette capital, et surtout de l'abbé Fortis").

37 The famous jurist and law professor Nicolò Caravita wrote the treatise Nullum jus romani Pontificis in Regnum neapolitanum. Dissertatio historico-juridica (The Roman Pontiff has no right over the Kingdom of Naples. Historic-juridical dissertation), Alethopoli 1707, which was inserted in the list of forbidden books in 1714. Another famous jurist who shared this view was Pietro Giannone, who was excommunicated. 
of the King's power, and their pride in his opposition to the abuse of Rome. Tellingly, she uses the Neapolitan dialect in this sonnet, which endows it with realism and a sense of immediacy. Although still contained here within poetic parameters, this attention to the language spoken by common people would become a pedagogical and political issue in her journalism. Her greatest contribution to the debate on the chinea and, thus, on the legitimacy of the claim of complete independence of the Kingdom of Naples from Rome, was the translation from Latin of the most important book on the topic, Nicolò Caravita's Nullum jus, dedicated to Ferdinand IV. ${ }^{38}$ She divided her work into two parts. In the first, she summarised the historical-juridical assumptions for the thesis by including the ideas and considerations of other authors on the issue. To craft this, quite original, introduction she had to draw on and expand her interest in public law. The second part, the translation itself, was accurate and in plain Italian. The translator contributed to educating and bringing the discussion to a larger audience: those who could not read Latin, but still wished to be informed on the topic without being discouraged by a specialised and unfamiliar language.

Together, with the progressive social experiment of San Leucio, the debate on the chinea had the effect of aligning the reformist court intellectuals with the King. They came to envision themselves as the advisors of a sovereign who could be mentored towards enlightened political choices and social reforms. However, as a consequence of the political situation in France, they were soon to be disabused of their hopes. Ferdinand IV and, especially, his wife Maria Carolina, were quick to recognise the cause of the people's unrest in the ideas and actions of intellectuals and philosophers. They reconnected with the Pope, while the intellectuals felt betrayed and began to follow with interest the developments of the French Revolution: a concretisation of Enlightenment ideals. ${ }^{39}$ According to Schiattarella, one can read this disaffection with the new political stance of the royals in Pimentel's refusal of translating from Portuguese a poetical composition penned by Luigi Raffaele Soye for Queen Maria Carolina's birthday in $1792 .^{40}$ This is also the year in which her last encomiastic work, La Fuga in Egitto, an oratory dedicated to Charlotte Bourbon, Queen of

38 N. Caravita, Niun diritto compete al Sommo Pontefice sul Regno di Napoli. Dissertazione storico-legale del Consigliere Caravita, tradotta dal latino ed illustrata con varie note da Eleonora Fonseca Pimentel, Alethopoli 179o. About Caravita see also note 37.

39 Pimentel's house in Plata della Salata was a meeting place for intellectuals who discussed French politics and read the French Monitore and, later, became the nucleus of the first Neapolitan Jacobin club.

Schiattarella, La Marchesa, 122. 
Portugal and Brazil, appeared. If this is still simply an ideological distancing from the monarchs, the dissemination of Jacobin ideas and clubs in France, and then in Italy and Naples, promoted the beginning of the activist phase for the Neapolitan intellectuals. Pimentel's formal adhesion to the Jacobin clubs, however, was impeded by her gender, her ties to the royal army through her exhusband and her brother and, most of all, by her financial dependence on the court through a pension.

Following the execution of Louis XVI and Marie Antoinette, Queen Maria Carolina instituted a network of spies who helped fill the jails with suspects, most of them held only for their political opinions. Pimentel was under surveillance due to her circle of friends and also because, after all, in her separation trial her own husband had accused her of reading French philosophes and of keeping company with the reformists. With her husband's death in 1795, she was finally completely free, although she had to fight with her brother-in-law in order to get part of her dowry back.

\section{Political Independence and Journalistic Activity}

Suddenly, in December 1797, her royal pension was suspended. That same year Napoleon had created the Cisalpine Republic, which quickly harboured scores of persecuted Neapolitan Jacobins. In Naples, the cultural repression employed preachers who roamed the city and the countryside depicting the Jacobins as devils. Foreign magazines were prohibited, and showing outward indications of foreign influence (such as growing a long beard or wearing long trousers) could warrant exile. Despite the warnings of her old friend de Souza, by 1798 Pimentel was fully adhered to the Jacobin cause and, in August, was arrested and taken to the prison of the Vicaria. The motivation for her arrest was never declared. She was held there for five months with common female criminals. At the arrival of the French general Championnette, the King and the court plundered the banks and fled to Palermo on General Nelson's ship. The people, revolting against the viceroy, freed all the prisoners. The Monitore di Roma announced Pimentel's liberation on this occasion, although there is evidence that at the beginning of January she had already asked for a loan to pay her past rent and the rent of a new apartment in S. Anna di Palazzo, her last domicile.

As soon as she was freed, Pimentel became an active member of the Jacobin committee that pushed for a democratic republican solution. Their most immediate goal was to facilitate the entrance of the French army into the city by taking away the strategic fort of Sant'Elmo from the lazzari, the populace loyal 
to the King. They managed to conquer Sant'Elmo on 20 January, and, apparently, Pimentel stood among the patriots that day, wearing male clothing. ${ }^{41}$ Unfortunately, only fragments survive of the Inno alla Libertà (Hymn to Freedom), the poem she declaimed during the ceremony of declaration of the Republic the following day.

Her most important contribution to this period, and for the majority of literary scholars, remains her work as probable founder, but surely director and journalist for the 35 numbers of the Monitore Napoletano: the main newspaper of the Neapolitan Republic. It is possible that she was entrusted with its direction not only because of her skills, but also because she kept out of any factionalism. Clearly, the other patriots also trusted her business skills as, in his Memorie, Giuseppe Maria Galanti wrote that "The Monitore was given to Eleonora Fonseca Pimentel so that she could get the profit from the sales". 42 Maybe this sentence suggests that she needed the profit from the journal to survive? ${ }^{43}$

A woman director of a political newspaper was an exception at that time. Elisabetta Caminer Turra, a good friend of Alberto Fortis who collaborated with her, had directed the Europa Letteraria since 1777, but that was a cultural journal, not a political newspaper. The Monitore di Roma announced the birth of the Monitore Napoletano thus emphasising the credentials of its director:

A praiseworthy citizen has accepted the task to write everything that will happen in Naples in a newspaper that she named "Monitore Napoletano". This newspaper will have all the merit that an illustrious and literate woman can bestow on it. On top of all her knowledge of sciences, even the most incomprehensible ones, she has command of many languages, among which Latin and Attic Greek are not the last. Her style has some brilliance since Apollo and the Muses did not spare with her their graces. ${ }^{44}$

42 "Il Monitore [...] si è dato ad Eleonora Fonseca Pimentel acciò ne ritraesse l'emolumento della vendita". Giuseppe Maria Galanti, Memorie storiche del mio tempo ed. D. Demarco, Napoli 1970.

43 Pimentel's personal possessions, which could easily fit in a pine box, were sold at an auction after her execution for a total of five ducats. For the detailed inventory see Schiattarella, La Marchesa, 194.

44 "Una benemerita cittadina ha preso sopra di sé l'incarico di stendere tutto ciò che succederà a Napoli in un foglio cui ha dato il nome di "Monitore napoletano". Esso foglio avrà tutto il merito che gli può conferire una donna illustre e letterata. Oltre tutte le cognizioni che la medesima ha delle scienze, benché le più abstruse, possiede eziandio più lingue, 
This period marks the very beginning of political journalism in Italy. In the Cisalpine Republic, it was a Neapolitan exile, Francesco Salfi, who directed the political newspaper Termometro politico di Lombardia. In Naples, before the Monitore Napoletano, only news of events such as spectacles, important weddings, celebrations and military ceremonies were published, without any educational intent. ${ }^{45}$ The Monitore, on the contrary, was a political publication with the declared purpose of reaching as many citizens as possible and of keeping them informed on current events and on the decisions of the republican government. Its first issue appeared on 2 February 1799. It was published twice a week and consisted of four large pages, generally beginning with Pimentel's editorial and reporting the news that collaborators and friends would send her from all over the Kingdom and the rest of the peninsula.

The director's foremost preoccupation, as is evident from her articles and from the epigraph to the last issues which reads "majestas populi", was to find ways to educate lower class people as an issue of moral justice, "right justice compels us to educate the people before condemning them, and each moment is late for this education", but also for political reasons since "the people are distrustful of the patriots because they do not understand them". ${ }^{46}$ Without the collaboration of the people, the existence of the Republic was in jeopardy. ${ }^{47}$ To reach her goal, Pimentel proposed some ingenious strategies. She appealed to the clergy asking them to preach to the people (like the royals had done before), and promoted the sale patriottiche (public places where the people met to be informed and to discuss politics) - even the popular puppet shows could be useful. ${ }^{48}$ Her deep knowledge of Neapolitan society allowed her to single

fra le quali la greca e la latina non tengono l'ultimo posto. Il suo stile ha qualcosa di brillante dopoché Apollo e le muse non furono secolei avare delle loro grazie". (Ibid., 155.)

45 During the Neapolitan Republic at least seven other newspapers and journals appeared regularly. The birth of the political press can be read as instrumental in the diffusion of ideas of political freedom and Italian national unity which, according to Croce, the Neapolitan patriots exported all over Italy: "They knocked down the barriers which separated the various regions of Italy, especially the Southern one from the Northern one, and they formed the common feeling of Italian nationality, not founding it, like before, on a common language and literature, and on the common memories of Rome, but on a common political feeling” (“[...] essi abbatterono le barriere che tenevano separate le varie regioni di Italia, specialmente la meridionale dalla settentrionale, e formarono il comune sentimento della nazionalità italiana, fondandolo non più, come prima, sulla comune lingua e letteratura e sulle comuni memorie di Roma, ma sopra un sentimento politico comune"). B. Croce, Storia del Regno di Napoli, Bari 1965, 229-30.

46 "l'esatta giustizia ci obbliga ad istruire la plebe, prima che condannarla, ed ogni momento è tardi per questa istruzione"; "la plebe diffida dei patrioti perché non gli intende".

47 Il Monitore Napoletano, 2/17 Piovoso, February 5, 1799.

48 C. Gily Reda, "Monitore Napolitano", in Giglio, Eleonora, 79. 
out powerful pedagogical allies in the vernacolo - the language spoken by the common people - and in Neapolitan religious beliefs and traditions. From the pages of the Monitore, she proposed the publication of a small newspaper in Neapolitan dialect containing the abstracts of the news to be read on Sundays, in all churches, by paid readers. ${ }^{49}$ Religion was the other important 'instrument' she suggested the patriots needed to appropriate in order to persuade and win the loyalty of the people. When Championette asked to be present in the cathedral to witness the miracle of Saint Gennaro's blood liquefaction and the 'miracle' did happen - Pimentel reported it on the Monitore describing it as a divine sign of acceptance of the Republic under the French protection, "Even San Gennaro has become Jacobin". 50

Pimentel's insistence on the need to use a language and a symbolism that people can understand, and to see things from the point of view of the 'other' in order to be effective in reaching one's goal, demonstrates not only her deep understanding of communication strategies, but also her belief that without unity there could be no strength in Italy's quest for freedom. In May, when the French troops abandoned the patriots to their fate, while the army of Cardinal Ruffo was marching towards the city, Pimentel wrote:

The present position of Italy is not a disadvantage: Italy will remain a warrior Nation, will fight equipped with her own, not with others' arms; they will understand the great truth, that a people never defends itself well if not by himself, and that an independent and free Italy is a useful ally; if dependent, it is a burden; because freedom cannot be loved halfway and it does not produce its miracles but among the people who are completely free..$^{51}$

Freedom cannot be loved halfway and can bear its fruits only among free people. Soon after writing these words Pimentel would become a martyr for freedom. Unfortunately, it is very likely that the destruction of the records and writings of the Neapolitan patriots ordered by the royals has deprived us of a wealth of information that would be helpful in reconstructing Pimentel's literary career.

49 Il Monitore Napoletano, 10/15 Ventoso, May 5, 1799.

$5^{\circ} \quad$ "Pure San Gennaro si è fatto giacobino!" Il Monitore Napoletano, 26/2o Fiorile, May 9, 1799.

51 "Lattuale posizione d'Italia, non è uno svantaggio: l'Italia resterà una Nazione guerriera, combatterà del suo, non dell'altrui ferro cinta; si comprenderà la gran verità, che un popolo non si difende mai bene, che da se stesso, e che l'Italia indipendente e libera, è utile alleata; dipendente, è di peso; perché la libertà non può amarsi per metà e non produce i suoi miracoli che presso i Popoli tutti affatto liberi". (Il Monitore Napoletano, 28/25 Fiorile, May 14, 1799.) 
From the very beginning, the personal, the political and the economic were strictly intertwined in her life. Her family's politics, visibility and social ties were decisive in shaping her education. She had easy access to intellectual circles, salons, academies and the court, where she was acclaimed for her talents as improvvisatrice and poetess. However, she belonged to the nobility and, although she was not particularly rich, her main objective seemed to be to obtain more than financial gain, but recognition for her poetic talent and active participation in the Neapolitan and Italian cultural discourse. An image of learned woman soon superseded her publicity as girl prodigy and she used her social connections to find mentors to further her knowledge in traditionally male subjects, such as mathematics, economics and law. Becoming the Queen's librarian was mostly a title of honour. Because of her husband's prejudices and jealousy, during her marriage she struggled to afford books for her studies, she had to fight for her right to maintain correspondence with intellectuals and to keep up her role in society and at court. Following the separation from her husband, she was forced to ask the King for a pension, thus obliging herself economically to the sovereigns through explicit economic ties. Once she lost her father, she intensified the production of poetic genres that were usually commissioned (sacred oratories, encomiastic poems, cantatas) and of translations: we can safely assume that she was trying to implement her meager finances with her intellectual work. One could argue that it was a newly found independence as a woman and writer, as her intensified interaction with the Neapolitan people due to her economic situation enhanced her ideological distancing from the court. The King's suspension of her pension on the grounds that, as a public intellectual, she was suspected of Jacobinism, completely freed her from ties of patronage to the court and provided her also with ideological freedom. During the brief life of the Neapolitan Republic, as director of the Monitore, the cittadina Eleonora Pimentel completely embraced the cause of political freedom in her journalistic writings, and even in the dignified acceptance of her exemplary death.

\section{Bibliography}

\section{Primary References}

Archivio di Stato di Napoli, fondo Gran Corte della Vicaria, ordinamento Zeni, fascio 133, fascicolo 43 .

Bergalli Gozzi, L. 1773. Rime di donne illustri a S.E. Caterina Dolfina cavaliera e procuratessa Tron, nel gloriosissimo ingresso alla dignità di procuratore per merito di S. Marco di S.E. il Cavaliere Andrea Tron. Venezia: Tip. P. Valvasense. 
Caravita, N. 1707. Nullum jus romani Pontificis in Regnum neapolitanum. Alethopoli: s.n.

Caravita, N. 179o. Niun diritto compete al Sommo Pontefice sul Regno di Napoli. Dissertazione storico-legale del Consigliere Caravita, tradotta dal latino ed illustrata con varie note da Eleonora Fonseca Pimentel. Alethopoli: s.n.

Componimenti poetici per le Leggi date alla nuova Popolazione di Santo Leucio da Ferdinando IV re delle Sicilie. 1789. Napoli: Stamperia Reale.

De Fonseca Pimentel, Eleonora. 1775. E. La nascita di Orfeo. Napoli: Raimondi.

De Fonseca Pimentel, Eleonora. 190o [1779]. 'Ode elegiaca di Altidora Esperetusa per un aborto, nel quale fu maestrevolmente assistita da M.R Pean il figlio', in Croce, B. (ed.) Sonetti di Altidora Esperetusa in morte del suo unico figlio. Napoli: Tip. Melfi e Joele.

De Fonseca Pimentel, Eleonora. 1782. La gioia d'Italia. Cantata per l'arrivo in Napoli delle LL. AA. RR. Il Gran Duca e la Gran Duchessa delle Russie. Napoli: s.n.

De Fonseca Pimentel, Eleonora. 1785. E. Il vero omaggio. Cantata per celebrare il fausto ritorno delle loro maestà. Napoli: s.n.

Gorani. 1793. Memoires secretes et critiques des cours, des gouvernemens et des mours des principaux états d l'Italie. Paris: Buisson.

Il Monitore Napoletano (2 febbraio-8 giugno 1799). 2008. (ed. A. Lerra). Menduria-BariRoma: Lacaita.

Urgnani, E. 1998. La vicenda letteraria e politica di Eleonora de Fonseca Pimentel. Napoli: La città del Sole.

\section{Secondary References}

Croce, B. 1965. Storia del Regno di Napoli. Bari: Laterza.

Croce, B. 1926. La Rivoluzione Napoletana del 1799. Bari: Laterza.

Croce, B. 1921. Curiosità storiche. Napoli: Ricciardi.

Croce, B. 1887. 'Eleonora de Fonseca Pimentel' in Rassegna degli interessi femminili. Roma: Tip. Nazionale.

De Liso, D. 1999. 'Sonetti (1770-1798)' in Giglio (1999): 81-120.

D’Episcopo, F. 2008. Eleonora de Fonseca Pimentel tra mito e storia. Napoli: Edizione Scientifiche Italiane.

Franchini, S. and Soldani, S. 2004. Percorsi e presenze di una storia di genere. Milano: FrancoAngeli.

Galanti, G.M. 1970. Memorie storiche del mio tempo. (ed. D. Demarco). Napoli: s.n.

Giglio, R. (ed.). 1999. Eleonora Fonseca Pimentel. Una donna tra le muse. Napoli: Loffredo Editore.

Gily Reda, C. 1999. 'Monitore Napolitano' in D'Episcopo (2008): 65-84.

Giorgio, Adalgisa. 2011. 'Eleonora de Fonseca Pimentel e la rivoluzione napoletana: Una donna eccezionale tra storia, memoria ed invenzione' in Italian Studies 66(3):301-17.

Minichini, S. 1999. 'Il Tempio della Gloria (1768)' in Giglio (1999): 25-81. 
Orefice, A. 2009. La penna e la spada. Napoli: Arte Tipografica Editrice.

Pisano, L. and Veuvy, C. 1994. Parole inascoltate. Roma: Editori Riuniti.

Porcelli, M. 2008. 'La poesía di Eleonora de Fonseca Pimentel' in D’Episcopo (2008): 23-39.

Rao, A.M. (2006) 'Eleonora de Fonseca Pimentel, le Monitore Napoletano et le problème de la participation politique' in Annales historiques de la Révolution française 344: 1791.

Schiattarella, F. 1973. La Marchesa giacobina. Napoli: Schettini Editore.

Urgnani, E. 1997. 'L'opera letteraria di Eleonora de Fonseca Pimentel' in Rivista di letteratura italiana XV. 